\title{
The Territorial-Environmental Perception in Fishing Zones (Amazon Region, Brazil)*
}

\author{
Christian Nunes da Silva, João Marcio Palheta da Silva, Clay Anderson Nunes Chagas \\ Federal University of Pará, (UFPA), Belém, Brazil

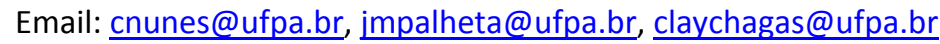

Received 2 August 2014; revised 22 September 2014; accepted 24 October 2014

Copyright (C) 2014 by authors and OALib.

This work is licensed under the Creative Commons Attribution International License (CC BY). http://creativecommons.org/licenses/by/4.0/

(c) (;) Open Access

\begin{abstract}
Geography was always concerned with the study of the relationship between social groups and the environment in which they interact as natural resources for their survival. This relationship was always intertwined by power determinations in the organization of forms of appropriation of natural resources, deriving different types of territorial assets. These territorial assets demonstrate a variety of actors, involved in a certain territory and materializing different actions for the appropriation of space and use of the natural resources. In the case of fishing this is not different, since we verified that fishing practice is witnessed by a variety of actors, fishermen, fishing community, fishing association, fishing zone and regulatory agencies. Each of these actors relate in specific ways to the fishing spaces and material specific actions to define the territory, adopting territorial assets and a diversity of perceptions which sometimes conflict with each other. This study is part of a research which, through direct field research, aims at accomplishing an analysis of the way of life of the fishermen of the Colony of Fishermen $\mathrm{Z}$ 62, headquartered in the municipal district of Breves, state of Pará, and how they acknowledge their territory, in the way they interact with other actors who use the same territory in other ways unrelated to fishing.
\end{abstract}

\section{Keywords}

Territory, Natural Resources, Territorial Perception

Subject Areas: Environmental Sciences, Human Geography, Sociology

\section{Introduction}

The global reorganization experienced currently permeates a new orientation with respect to the materialization

*This paper is a review translated to English language, of text published in 2007, entitled "The Territorial-Environmental Perception in Fishing Zones” and divulged in the Emílio Goeldi Museum Bulletin. The Portuguese version is available for consultation at site:

http://www.museu-goeldi.br/editora/bh/artigos/chv2n3 2007/percepcao\%28silva\%29.pdf. The research of origin is part of the project "Participatory Mapping and survival strategies of traditional populations in the Amazon Pará” with funding from the National Council for Scientific and Technological Development-CNPq. 
of the human-nature relationships. The aim is to overcome the traditional understanding of the role of nature to be a mere object, then being used as stock and supplier of natural resources, at the mercy of the purposes of civilized man. More and more men try to reverse the situation represented by the perversity in which men practice their actions on nature to accomplish the expansion process intensifying the use of natural resources. This context shows the intention of searching the seated economic development in the area of nature by man.

This situation reaches a limit that reveals the unsustainability of the development proposal, in view of the exhaustibility of resources and the intense degradation of the environment. Therefore, new ethical values are determined beyond a compartmentalized view that exists between society and nature. It becomes important to highlight the relevance of geographical discussions to compose the analytical scenery of the environmentalist's question, since the geography has always had an agenda appropriation of space as a product of the man-means. For effectiveness in production of space for man, using the technique contributed to the degradation of the environment and to the pillaging of natural resources.

This reality is not different in the case of fishing activity, because it is a natural resource whose consumption is increasing as the market demand for fish increases. This process reflects directly on the means and manner of fishing production in the Amazon region, since the territoriality of fishermen is a practice that should be taken into account when it proposes a kind of planning for this activity, because fishermen recognize their fishing territories, the common use of a certain fraction of the population, and in the case studied here, the territories of fishermen of the Fishing Colony Z 62 to a Z 62.

\section{Environmental Perception-Territorial and Fisheries}

Territoriality can be proven in any study that aims to analyze how the performance of the society is in the geographic space. Thus, the ways of life and territoriality are the products and reflection of the performance of individuals in space and use of natural resources. The ways of life of fishermen and fishing territories themselves affirm, interact, otherwise do not speak in way of life and territory-humanized, but rather only the common characteristics of living animals, which interact with the space making it a mere support for life, without thinking about it and without construction, then without intentionality. This way, in the analysis of territoriality of fishermen it is verified that several mechanisms and/or processes are part of the training of their ways of life and their territoriality ${ }^{1}$.

With multiple realities/territorialities, it is verified that the fishery is complex. Mechanisms and techniques such as geoprocessing, tend to optimize the actions of fishermen - artisanal and industrial, and the government, despite the "open access". It is notorious that in reality the fishing areas have an "abstract" territorial delimitation that requires rules and agreements between fishermen [1] and which may be intermediated by governmental agencies.

The environmental perception that has fishermen of the area studied in this work is closely related to the territory they inhabit and work, causing an identity of themselves with this space. So, the geographical and environmental/territorial perception what one has of the lived space constitutes a key point to understand the reality studied.

Thus, the environment is a reference point for studies that make direct relationship between society and the environment, because the relationship between the two elements shows how society perceives and acts, modifying the territory of influence, through their customs and techniques, or by way of a cemented life [2]. Therefore, identifying themselves with the territory of society acquires and recognizes that space as part of their own identity, as an integral element of their way of life, which may require it as a nation, or in the specific case of this work, whereas the area of influence and experience-a fishing zone-where they occur, daily, traditional work activities of a group of individuals.

The perception and the consequent symbolism are given to the territory to interact with economic and social aspects, producing and modifying the collective culture. So, identification and self-knowledge of the individual with the territory in which it works and lives is striking point for the recognition of a collective-segregationist, since these elements separate-since determinations can occur and at the same time join, because it is a population or community with its own characteristics, ordering this way, the territory in which they live.

It is important to emphasize that artisanal fishermen, as already shown by other authors [3]-[6] do not seek fisheries resources by chance, but seek them in specific locations of aquatic environments. These studies dem-

\footnotetext{
${ }^{1}$ Territoriality in this article is defined as the attempt to affect, influence or control actions, interactions, or access by asserting and attempting or to enforce control over a specific geographic area.
} 
onstrate that the fisheries are ecologically located, with a degree of mobility according to each species, finding themselves in "spots", i.e. according to Begossi [4], verifies, what fishermen refer to as "fishing", are actually stains of fish, or places where certain species are found.

In these aspects, the territorial perception of artisanal fishermen of $\mathrm{Z} 62$, combined with knowledge of the ecology of fish, is of fundamental importance for the understanding of creation and strengthening their territorialities. Like artisanal fishers are located, map their territory of operation should be considered. However, how the artisanal fishermen map its territory of activity must be shown by the very fishermen.

The mapping carried out with the help of fishermen demonstrates the territoriality of them in areas of the fish activity. Therefore, in the Ituquara River, a major river which practices traditional fishing in the municipality of Breves, spots or stains referred to as fishing [4], this is, the territories where the fishermen extract the fishery resources, demonstrate the influence areas of fishermen, their territoriality and how these express themselves spatially, in view of the territoriality of all other users of fishing or river. Being that if somehow that territoriality of the fisherman exceeded without their consent, is likely to occur a conflict for resources contained in that space.

In the Ituquara River, the field research sought to identify the main fishing grounds used by fishermen, members of the colony Z 62 and also by fishermen coming from other places. Thus, the elements often lead to more conflicts can be seen in the following Table 1, evidencing that a large part of them resides in breaking rules in the use and extraction of fish.

One realizes that the conflicts are directly related to natural resources that besides the fishermen, are appropriated and occupied by other social groups, with own purposes and characteristics. Therefore, when several actors seek the same resource, in the same space, conflicts occur at the prospect of losing, because these territories juxtaposed and overlap, creating areas of intersection and conflict between them, in other words, those territories that are recognized as possessing more than one user.

The Map 1 below shows the materialization of these fishing grounds, reported by artisanal fishermen during field research in Ituquara River [7]. One can verify that some fisheries and their areas of influence are superimposed, in these cases, if there is no release of the "owner of the fishing", the conflict may become inevitable.

When the fish becomes scarce in other rivers near the area of activity of $Z 62$, the fishermen from other colonies invade the territory of the $Z$ 62 . This fact has promoted a series of confusions between fishermen of different zones, who complain of the competition for fisheries. The fishermen of Z 62 consider it an invasion because it concerns fishermen from "outside" that go to the rivers of Breves extracting the fishery resources and not engage in local manpower in the fishing activity. The solutions to this impasse are the "fishing agreements", signed between fishermen from different colonies, this is, the establishment of rules that determine the extraction of fish in certain regions [8].

The preparation of these "fishing agreements", establish rules for the use of fisheries resources, with the objective not to create conflicts among users. These agreements do not presuppose its legalization by the government in order to be effective among fishermen. Furtado [9] verifies that (...) these "laws" commonly called "agreements" and are written by members of fishing communities in general meetings of their associations. Begossi [4] analyzes this reality in his study on the Brazilian coast and rivers, where the question of limits, of territoriality among the fishermen are solved with these agreements between the participants, in most cases informal agreements, not determined, but recognized by fishermen for their daily lives and cultural habits.

Table 1. Conflicts in river environments in the Amazon region. (Source: Field research, 2013).

\begin{tabular}{|c|c|c|}
\hline Types of conflicts & Cause & Consequence \\
\hline Local fishermen versus other local fishermen & Invasion of fishing grounds & Fights and even murder cases \\
\hline $\begin{array}{l}\text { Local fishermen versus vessels that pass } \\
\text { through the rivers }\end{array}$ & $\begin{array}{l}\text { Garbage thrown by vessels that can curl up } \\
\text { and punch fishing nets }\end{array}$ & Polluted river and torn nets \\
\hline $\begin{array}{l}\text { Local fishermen versus } \\
\text { fishermen from outside }\end{array}$ & Fishing territories & $\begin{array}{l}\text { Fights without homicides until the } \\
\text { moment }\end{array}$ \\
\hline $\begin{array}{l}\text { Local fishermen versus inspection agencies } \\
\text { (Ibama, municipal and state secretaries) }\end{array}$ & Lack of supervision and/or excessive surveillance. & $\begin{array}{l}\text { Noncompliance of legal norms to } \\
\text { regional fisheries }\end{array}$ \\
\hline $\begin{array}{l}\text { Local fishermen versus members of } \\
\text { non-governmental organizations (Unions, } \\
\text { colonies, associations, etc.) }\end{array}$ & Denounces of illegal fishing & Fights and even murder cases \\
\hline
\end{tabular}




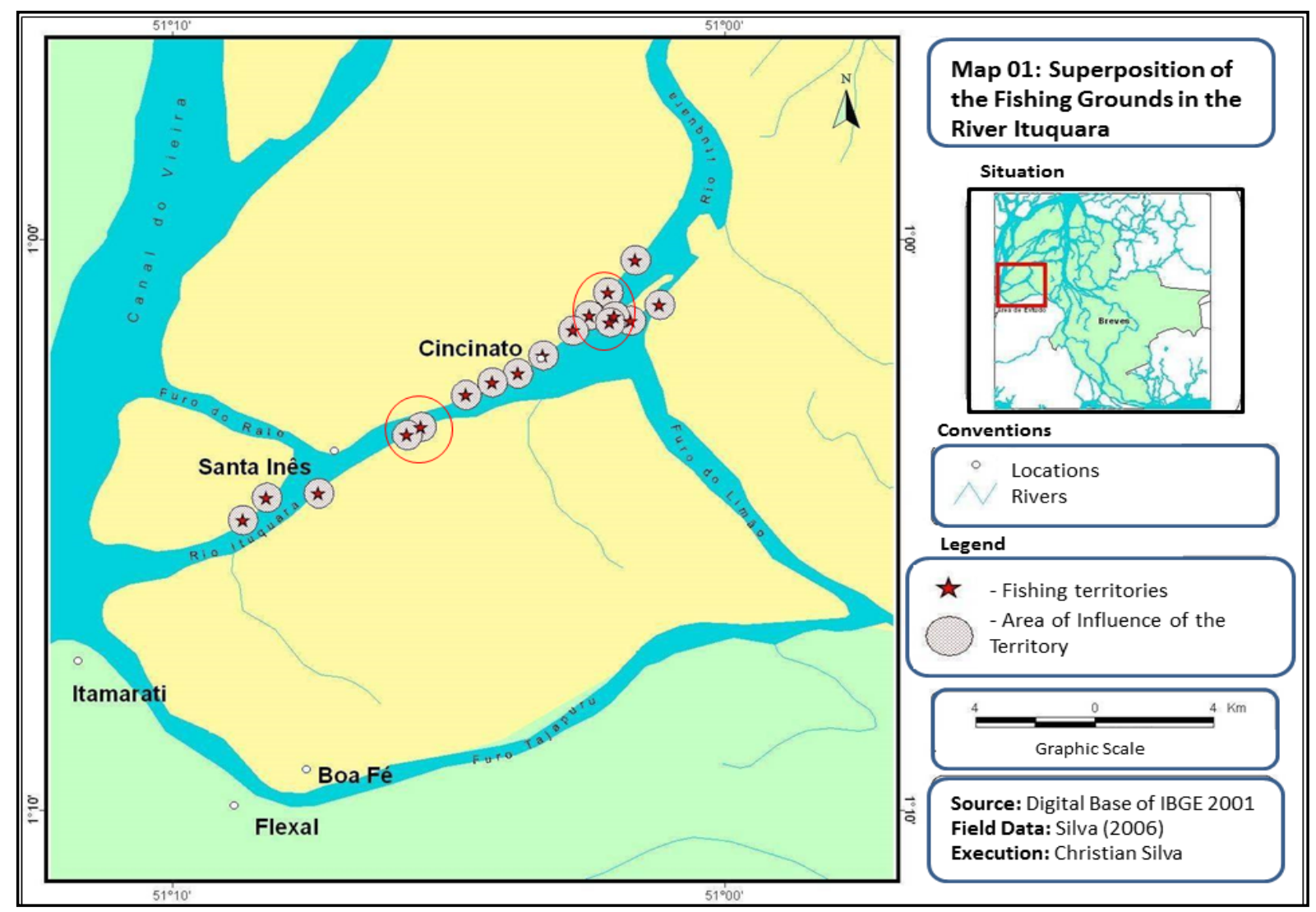

Map 1. Conflicts in river environments in the Amazon region. (Source: Field research, 2006).

Begossi [4] (p. 226) notes that: "With respect to the application of the concept of territoriality to human populations, it is worth remembering that conflicts are often resolved through agreements or rules, informal or formal, or just cultural customs or customary laws (customary laws). Cordell observed, in Bahia, there was no need to be physically present for the defense of a fishing ground, because the concept of respect was enough to mark ownership of this fishing ground" [4].

Fisheries agreements do not exist in the River Ituquara. However, the rules of conduct created informally by local fishermen are perceived and respected. In the harvest period these agreements are extended to fishermen from outside the sector, who do not live in that river and, sometimes, neither in the municipality of Breves [10] [11]. It concerns fishermen from other municipalities and other colonies during the months of harvest of fish enter in the River Ituquara to their benefit to fishing resources. According to field research, these fishermen are mainly from the municipalities of Abaetetuba, Barcarena, Belém, Cametá, Curralinho, Gurupá, Igarapé-Miri, Melgaço, Monte Alegre, Soure, among others.

In this sense, based on the field surveys to identify fishing areas of the River Ituquara [12], one can perceive some territorial peculiarities that highlight fishing resources and that distinguish them from terrestrial resources that:

- are moveable, because animals and plants "transit", or move according to the dynamics of tides, floods and drought periods and with their life cycles. The mobility of the fishing industry also has to do with the type of transportation technology that will enable the fisherman to stock more fish, or reach greater distances or not the demand for fish;

- are not limited by specific boundaries, but by imaginary boundaries, abstract, recognized by fishermen. Therefore, the work area where the fishing activity is carried out is not physically limited, as in agriculture, because it concerns a mobile resource — fish, however what is more significant in certain places—-the fishing grounds;

- are spatially fluids, because these resources are concentrated in strategic locations that artisanal fishermen 
denominate of fishing, although these fisheries have a fluid volume that is characterized as the amount of fish which is extracted. What one sees, observed in the research field in the River Ituquara is that measures for conservation of fishery resources do not occur for increased extraction that reflect the decreased supply of these resources by the environment. The reverse process can be observed when the fishing is going through a period of "rest", preservation or a form of "fallow" characterized by spawning;

- are ecologically unstable, due to their availability depends on the environment in which they are inserted, because they can end up, if the extraction exceeds the support capacity, and resources are not replaced with obedience to the time of spawning;

- are public resources, because all the aquatic environment and the organisms that inhabit therein are in the public domain and, therefore freely accessible for exploitation by all persons duly authorized;

- are unpredictable economic resources, because their availability is given by the impositions of natural factors on fishing activity, for example the climate and geomorphology of watercourses.

- are temporally unpredictable resources, because fishing is regulated by the harvest and fishermen during the fishing does not have time to for the right job, like with workers who carry out their activities in terrestrial environments.

These peculiarities make the fishermen are obliged, because they need it for subsistence, to become knowledgeable of the water environment from which extract their sustenance. Studies on artisanal fisheries allow the generation of more information about the importance of livelihoods of fishermen [12]. In the specific case here of the fishermen of the river Ituquara in the Amazon estuary which noted the way they territorialize in space in which they operate and who appear to be very different from fishermen operating in the Brazilian coastal area. The difference is the environment in which they operate (River x Sea), but are similar in lifestyles and the construction of territories.

\section{Conclusions}

The fishing activity is known from the earliest ages of mankind, when the man was adjusting to the external environment with the objective to meet one of their most basic needs: food. Over the years new technologies has increased the performance possibilities of the fisherman, with the direction of increased production, not only for the satisfaction of their basic needs, but also for their material needs. Therefore, several authors are concerned and perform research on the activities of man and his way of life, with the main area of the research on the working environment that includes fishing, whether artisan, industrial or other.

There is no doubt about the importance of fishing activity in the present moment where fisheries represent the primary source of income for fishermen and guarantee a portion of the diet of inhabitants, both in city and rural areas. The events that occur now demonstrate that fishermen and artisanal fishers will have to adapt to today's time, because the external influence to fishing is inevitable, even more in the globalization process, where new technologies emerge and new consumer markets are created, generating demand for food products, including products from the fishing activity.

Through further analysis of realities such as the one that occurs in the River Ituquara-there are possibilities for further studies where the materialization of fisheries can be mapped and represented; there are possibilities for further studies in which artisanal fishermen, besides being the main suppliers of fish to large metropolitan areas have their ways of life, as well as their territorialities, guaranteeing the preservation of their cultures and traditional ways of subsistence.

\section{Funding}

This research was funded by the Qualified Publication Support Program (PAPQ), offered by the Dean of Research and Graduate Studies (PROPESP) and the Foundation for the Support and Development of Research (FADESP), of the Federal University of Pará.

\section{References}

[1] Ruffino, M.L. (2005) Gestão do uso dos recursos pesqueiros na Amazônia. IBAMA, Manaus.

[2] Paul Vidal de, L.B. (1954) Princípios de geografia humana. 2. ed. [s. l.], Cosmos.

[3] Begossi, A. (2001) Mapping Spots: Fishing Areas or Territories among Islanders of the Atlantic Forest (Brasil). Re- 
gional Environmental Change, 2, 1-12.

[4] Begossi, A. (2004) Áreas, pontos de pesca, pesqueiros e territórios na pesca artesanal. In: Ecologia de pescadores da Mata Atlântica e da Amazônia, Hucitec, São Paulo, 223-255.

[5] Begossi, A. (org.) (2004) Ecologia de pescadores da Mata Atlântica e da Amazônia. Hucitec, São Paulo.

[6] Maldonado, S.C. (1993) Mestre \& mares: Espaço e indivisão na pesca marítima. Annablume, São Paulo.

[7] Silva, C.N. (2006) Territorialidades e modo de vida de pescadores do rio Ituquara, Breves—PA. UFPA, Belém.

[8] Mcgrath, D.G. and Câmara, E.P.L. (1995) A viabilidade da Reserva de Lago como unidade de manejo sustentável dos recursos da várzea. Boletim do Museu Paraense Emílio Goeldi. Boletim do MPEG, Belém, 87-132.

[9] Lourdes, F. (1994) Comunidades tradicionais: Sobrevivência e preservação ambiental. In: Amazônia e a crise da modernização, MPEG, Belém.

[10] Silva, C.N. (2008) Cartografia das percepções ambientais-territoriais dos pescadores do estuário amazônico com utilização de instrumentos de geoinformação. Revista Formação, 1, 118-128.

[11] Silva, C.N. (2009) Caminhos e lugares da Amazônia: ciência, natureza e território. 01 ed., v. 1, GAPTA/UFPA, Belém, 35-54.

[12] Silva, C.N. (2007). The Territorial-Environmental Perception in Fishing Zones. Boletim do Museu Paraense Emílio Goeldi. Ciências Humanas, Belém, 2, 25-32.

http://www.museu-goeldi.br/editora/bh/artigos/chv2n3 2007/percepcao\%28silva\%29.pdf 